\title{
硫酸劣化したモルタルのセメント水和組織の変質と 準微視的力学的性質との関係
}

\author{
三浦 泰人 $*^{1} \cdot$ 佐藤 靖彦 $*^{2} \cdot$ 中村 光 $^{3}$
}

\begin{abstract}
概要: 硫酸溶液を用いたモルタルの薄片供試体による最大 60 日間における浸漬実験を行った。その目的は, 浸漬後 に曲げ試験およびせん断試験を行うことで, 硫酸劣化によりセメント水和組織が変質した薄片供試体における力学的 性質の挙動を抽出することにある。本研究において, 曲代試験から得られる荷重変位曲線から逆解析により引張特性

(弾性係数, 引張強度, 破壊エネルギー, 引張軟化曲線）を同定し, 同一試験体を用いてせん断試験を行うことでせ ん断強度を測定した。加えて, 物理的性質として力学試験後の薄片供試体の水和物量 (CH, C-S-H), 析出物, 空隙 率, 細孔径分布を測定することで, 物理的性質と力学的性質の変化を関連付けた。最終的に, 硫酸劣化による物理的 性質の変化が力学的性質に及ぼす影響は, 弾性係数と引張強度および破壊エネルギーとせん断強度とで異なることを 明らかにした。さらに，空隙と強度の関係に基づく既往の提案モデルの適用性を評価した。
\end{abstract}

キーワード: 硫酸, 水和物, 空隙率, 空隙構造, 引張特性, せん断強度

\section{1. はじめに}

硫酸劣化は, 下水道処理施設や温泉地のコンクリート 構造物において問題視されている劣化現象 ${ }^{1), 2), 3) て ゙ あ る 。 ~}$ 硫酸劣化は種々の化学的劣化現象の中でも劣化の進行が 速く, また, 配合条件や環境条件によりその劣化形態が 異なることが知られている。

これまでに, 硫酸劣化に関する多くの実験的・解析的 検討例えば 4) が行われてきたが，力学的な側面から硫酸劣 化を論じた研究は少ない。例えば, 大脇ら ${ }^{5)}$ は, 硫酸劣 化の進展に伴ってモルタルの圧縮強度および弾性係数が 増減することを, 「空隙の充填一久陥の発生」というプロ セスの連続から生じるとした。久田ら ${ }^{6}$ は, モルタルの 薄片供試体による硫酸の浸漬実験を行い, 曲げ強度と物 理化学的性質との関連を評価した。このほかにも, 硫酸 劣化による曲げ強度の推移をモデル化した研究報告 ${ }^{2), 7), ~}$ 8), 9)がいくつかある。しかしながら, 現状では, 硫酸劣化 によるコンクリート構造物の構造性能の推移を評価およ び予測できるまでには至っていない。

本研究の最終的な目的は, 硫酸劣化によるコンクリー 卜構造物の構造性能の変化を解析上で表現することであ る。その解析とは, 流水などの外力による断面減少と劣 化が深く進んだ際の耐力低下までを評価・予測が可能な ものである。本稿では, その第一段階として, 硫酸劣化
によって変化する物理化学的性質と力学的性質とを同一 領域において平均化することで，両者の関連付けを行っ た。その際，久田らの研究 ${ }^{6}$ を参考にして，平均化する 領域を $5 \mathrm{~mm}$ のメソスケールの領域とした。

本研究では, 水和物および空隙といった物理化学的性 質の変化に伴う力学的性質 (弾性係数, 曲げ強度, 引張 強度, 破壊エネルギー, せん断強度）の変化を, メソス ケールの領域において定量的に同定することに主眼を置 いた実験的検討（図ー1）を行った。すなわち，薄片供試 体による硫酸溶液の浸漬実験を行い, 浸漬後の薄片供試 体を用いて 3 点曲げ試験（以下，曲げ試験）を行うこと で荷重変位曲線を測定し, 得られた荷重変位曲線から弾 性係数を算出するとともに, 逆解析により引張強度, 破 壊エネルギー，引張軟化曲線を同定した。さらに，曲げ 試験後の 2 つに分断された薄片供試体を用いて, 直接二 面せん断試験（以下，せん断試験）を行うことでせん断 強度を測定した。これに加えて, セメント水和物の主成 分である CH およびC-S-H の定量分析, X 線回折 (以下, XRD）による析出物の生成の有無, 空隙率や細孔径分布 をアルキメデス法もしくは水銀圧入法によって測定した。 これらの実験的検討に基づいて, 硫酸劣化による物理化 学的性質の変化とそれに伴う力学的性質の変化を関連付 けた。最終的に，著者らが提案した既往のモデル式の適 用を試みた。

*1 名古屋大学大学院工学研究科社会基盤工学専攻 助教 (正会員) $\overline{7} 464-8603$ 愛知県名古屋市千種区不老町

*2 北海道大学大学院工学研究科 准教授 (正会員) $\bar{\top} 060-8628$ 北海道札幌市北区北 13 条西 8 丁目

*3 名古屋大学大学院工学研究科社会基盤工学専攻 教授 (正会員) $\bar{T} 464-8603$ 愛知県名古屋市千種区不老町 


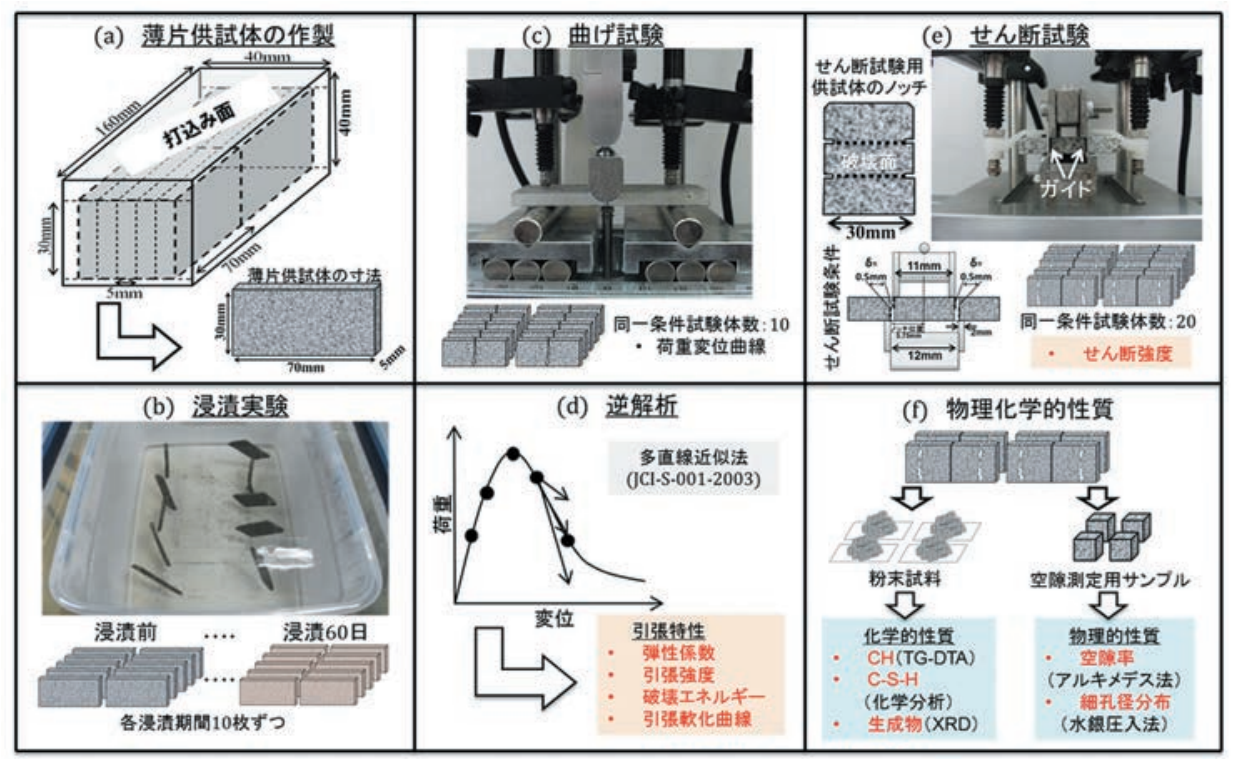

図-1 実験的検討のフロー

\section{2. 実験概要}

\section{1 使用材料}

使用したセメントは普通ポルトランドセメントとし, 化学混和剤は使用しなかった。水とセメントと細骨材の 質量比を $1: 2: 6$ としたモルタルを作製した。まず，練 り混ぜにはモルタルミキサーを使用し，40×40×160 mm の角柱供試体を作製した。脱型後, 水中にて 60 日間養生 した。なお，細骨材の絶乾密度および粗粒率は，それぞ れ $2.71 \mathrm{~g} / \mathrm{cm}^{3}, 2.82 \%$ ありり, 川砂を使用した。細骨材の 最大骨材粒径は，節を用いて $1.7 \mathrm{~mm}$ （薄片供試体の厚 さ: $5 \mathrm{~mm}$ の約 3 分の 1) となるように調整した。

\section{2 薄片供試体の作製}

養生終了後, ブリーディングの影響を考慮して, 角柱 供試体内部から，湿式コンクリートカッターを用いて, 厚さ : $5 \mathrm{~mm}$, 幅 : $30 \mathrm{~mm}$, 長さ : $70 \mathrm{~mm}$ の薄片供試体を 作製した（図一1(a)）。なお，切断の精度は土 $0.5 \mathrm{~mm}$ で ある。

\section{3 実験条件}

(1) 浸漬実験

硫酸溶液は, 濃度 97\%の硫酸とイオン交換水を使用し, 硫酸イオン濃度が $2500 \mathrm{mg} / \mathrm{L}$ となるように作製した。 Gabrisova ${ }^{10)}$ は, $\mathrm{pH}$ と二水セッコウの溶解度の関係からエ トリンガイトの析出条件を明らかにした。これによれば, $\mathrm{pH}=10.7$ 以上（アルカリ側）では二水セッコウが溶解し ないためエトリンガイトが析出しない。本実験で用いた 硫酸溶液は，全浸漬期間を通して $\mathrm{pH}$ が 4 程度に維持さ れる浸漬条件であることから，二水セッコウの析出が支 配的となる条件となっている。

浸漬実験に使用した容器は, 耐薬品性に優れるポリ容 器を使用した。10枚の薄片供試体を溶液量 $15 \mathrm{~L}$ に調整し たポリ容器に投入した。このとき, 10 枚の薄片供試体と
溶液量の体積比は, 約 $0.7 \mathrm{~cm}^{3} / \mathrm{L}$ である。薄片供試体を浸 漬する際，耐腐食性の糸を用いて薄片供試体を吊り下げ るようにし，静水条件下において浸漬した（図一1(b))。 薄片供試体を投入する前に, 24 時間イオン交換水中にプ レウェッティングし，表面の余分な水分を取り除いた後 に硫酸溶液に浸漬させることで, 薄片供試体の乾燥によ る硫酸溶液の薄片供試体内部への浸透を防ぎ, 反応が硫 酸イオンの移動によって支配されるようにした。なお,

プレウェッティング中の薄片供試体の水和反応および $\mathrm{Ca}$ 溶脱の影響は無視できるものとした。浸漬期間は 0 , 15，30，45，60 日間とし，浸漬終了ごとに 10 枚の薄片 供試体を同一容器から取り出した。なお, 浸漬 30 日に溶 液を全量交換した。浸漬実験は温度が $20^{\circ} \mathrm{C}$ と一定に保た れた環境室において行った。

(2) 力学試験

浸漬期間終了ごとに，薄片供試体を 10 枚取り出し， 曲げ試験（図ー1 (c)）の写真に示すような 3 点曲げ試験 を行った。本研究では, 引張軟化曲線を同定することを 目的としていることから，ひび割れ発生後の軟化域を測 定するために精度の高い変位の測定が必要となる。そこ で, 載荷点直下および支点に $1 \mu \mathrm{m}$ まで測定可能な LVDT 変位センサーを設置し, 支点間距離 : $50 \mathrm{~mm}$, 載荷速度 : $1 \mu \mathrm{m} / \mathrm{sec}$ とした変位制御により破壊に至らしめた。なお, 浸漬後の薄片供試体を真空デシケータ内に置き，真空ポ ンプにより減圧した状態（以下，減圧環境）に 1 日間静 置して薄片供試体内の水分をある程度取り除くことで, 水分条件の違いが曲げ試験に及ぼす影響を可能な限り小 さくなるようにした。

次に，曲げ試験後の 2 つに分断された 20 枚の薄片供 試体を用いて，支点および載荷点から $5 \mathrm{~mm}$ 以上離れた 箇所でせん断試験（図ー1(e)）を行った。本せん断試験 法は, 魚本らの研究 ${ }^{11)}$ を参考にして, 比較的安定したせ 
几断強度が測定可能な直接二面せん断試験 ${ }^{12)}$ を採用し た。せん断試験に用いた上下部の治具（それぞれの自重 は $0.01 \mathrm{~N}$ 程度）は, 薄片供試体のわずかな傾きにも対応 可能なものである。すなわち，上下部の治具はそれぞれ 中心治具と薄片供試体と接触する 2 つの平板状の治具

(以下，平板治具）で構成されており，それらを薄片供 試体の形状に合わせてネジで固定することで, 薄片供試 体と平板治具が隙間なく接触するようにした。なお，平 板治具の厚さを $2 \mathrm{~mm}$ ，上下部治具のずれを $0.5 \mathrm{~mm}$ と設 定した。加えて, 上下部治具のずれの位置においてせん 断破壊を促すために, ずれの位置の中心に, 薄片供試体 の幅を減らすように幅 $1 \mathrm{~mm}$, 深さ $5 \mathrm{~mm}$ のノッチを設け た。上下部の治具や薄片供試体の設置時の人為的な影響 を取り除くために，厚さ $0.8 \mathrm{~mm}$ のガイドを上下部治具 のずれの位置と薄片供試体のノッチ部に挿入することで, 試験の簡便化ならびに精度の向上を図った。なお，曲げ

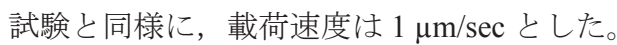

（3）引張軟化曲線の同定

引張軟化曲線の同定に使用した解析プログラムは, JCI-S-001-2003 において推奨される「多直線近似法によ る引張軟化曲線の推定」 ${ }^{13)}$ を用いた (図ー1 (d))。これは, 有限要素法によって試験体を仮想ひび割れ部と線形弾性 部に表現し, 破壊が仮想ひび割れ部において離散的に生 じると仮定したモデルである。この解析プログラムを用 いて曲げ試験から得られた荷重変位曲線から逆解析によ り引張軟化曲線を推定した。なお, 最大ひび割れ幅は, 推定された引張軟化曲線の終点およびその直前の点を結 ぶ直線と $\mathrm{x}$ 軸との交点とし, 破壊エネルギーは引張軟化 曲線下の面積とした。

(4) 物理化学的性質の同定

本研究では, 硫酸劣化により時間軸上で変化する薄片 供試体中の物理化学的性質を定量的に評価することが肝 要となる。そこで, 薄片供試体の化学的性質として, セ メント水和物中の主要成分である CHとC-S-Hの定量分 析と析出物の有無を, 物理的性質として薄片供試体の空 隙率および細孔径分布を評価した（図ー1 (f))。具体的に は, せん断試験後, 曲げ試験時では10体であった薄片供 試体の中から4体の薄片供試体を無作為に選出した上で, それぞれの薄片供試体から1体ずつ一辺およそ5 mmの角 型試料を4体作製し,これらを物理的性質の分析に使用し た。残りの薄片供試体を用いて, 鉄乳鉢によって粗粉砕 し, 遊星ボールミルを用いて粒径が40 $\mu \mathrm{m}$ 以下となる粉 末試料を作製し，化学的性質の分析に用いた。なお，炭 酸化や粉砕時の発熱の影響を考慮して，粉末試料の作製 中はアセトンを用いることで，外気との接触を防ぐとと もに粉末試料作製時の発熱を低減させた。また，作製し た試料は分析まで真空デシケータ内の減圧環境下にて保 管した。

化学的性質の測定 ${ }^{14)}$ では, 粉末試料を用いて, CHは示
差熱質量同時分析（TG-DTA）を，C-S-Hは重液分離法お よびサリチル酸メタノール法による化学分析によって分 析した。重液分離法には，粉末試料に密度が $2.4 \mathrm{~g} / \mathrm{cm}^{3}$ と なるように調整したブロモホルムとエタノールの重液を 用い，遠心分離機によって骨材やクリンカー鉱物などの 未水和セメント成分とセメント硬化体とに分離した。こ

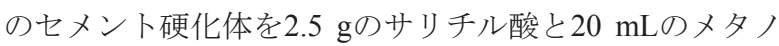
ールの混合溶液で溶解させて，薄片供試体中のC-S-H量 を測定した。また，析出物の有無はXRDによって評価し た。なお，CHおよびC-S-Hは全浸漬期間において4つ, 析出物の有無は浸漬 $0 ， 30 ， 60$ 日の $1 つ の$ 粉末試料の結果 を用いた。物理的性質の測定 ${ }^{14)}$ では, 角型試料を用いて, 空隙率はアルキメデス法, 細孔径分布は水銀圧入法によ つて測定した。なお，アルキメデス法は，角型試料の乾 燥質量 : $w_{d}$, 湿潤質量 : $w_{s}$, 湿潤体積 : $V_{s}$, 水の密度 : $\rho_{w}$ から，以下の式により空隙率 : $p$ を算出する手法である。

$$
p=\frac{\left(w_{s}-w_{d}\right)}{V_{s}} \cdot \frac{1}{\rho_{w}}
$$

水銀圧入法に関しては, 24時間D-dry乾燥させた角型試 料を用いて, $0.01 \sim 10 \mu \mathrm{m} の$ 空隙量を測定した。なお，空 隙率の測定は全浸漬期間において 3 体, 細孔径分布は全浸 漬期間において1体の角型試料の結果を用いた。

\section{3. 実験結果と考察}

\section{1 物理化学的性質の変化}

（1）薄片供試体の外観変化および中性化領域の推移

写真－1 に曲げ試験後の薄片供試体の外観および薄片 供試体の断面と中性化領域の様子を示す。中性化領域の 可視化には，エタノールに質量比で $1 \%$ の粉末状のフェ ノールフタレインを混合したフェノールフタレイン溶液 を用いた。

薄片供試体の外観は，浸漬期間の増加に伴って表面の 白色化が進行するとともに，断面減少が確認された。浸 漬 45 日以降の薄片供試体に至っては二水セッコウの析 出に伴う微細なひび割れの発生による脆弱化によって骨 材の露出が確認された。また, 薄片供試体の断面の中性 化領域をみると，経時的に中性化領域が薄片供試体内部 方向に進行していることが確認できる。浸漬 60 日が経過 した時点では，薄片供試体の内部においてもフェノール フタレイン溶液による赤紫色の呈色がみられない。この 呈色反応は, $\mathrm{CH}$ 中の水酸化物イオンとの反応によるも のであることから， CH の消失が薄片供試体内部まで進 行しているものと考えられる。

（2）物理的性質の経時変化

図-2 に硫酸溶液に浸漬させた薄片供試体中の $\mathrm{CH}$ 量 
および C-S-H 量の経時変化を, 図ー3 に XRD の結果を示 す。

図－2 によると，薄片供試体中の $\mathrm{CH}$ 量は概ね一定の 割合で減少し, 浸漬 60 日では $\mathrm{CH}$ の消失が確認された。 これは, 浸漬 60 日経過後の薄片供試体の断面においてフ エノールフタレイン溶液による赤紫色の呈色反応がなか ったことと一致する。また, 薄片供試体中の C-S-H 量は, 浸漬 15 日まで若干増大し, それ以降は減少した。浸漬 60 日の C-S-H 量は浸漬前の C-S-H 量と比較して 12\%程 度であった。XRDの結果 (図一3) をみると, 浸漬 30 日, 60 日において二水セッコウの析出が，さらに，浸漬 30 日にエトリンガイトの析出が確認された。

図-4 6に, 空隙率, 総空隙量, 細孔径分布の経時変

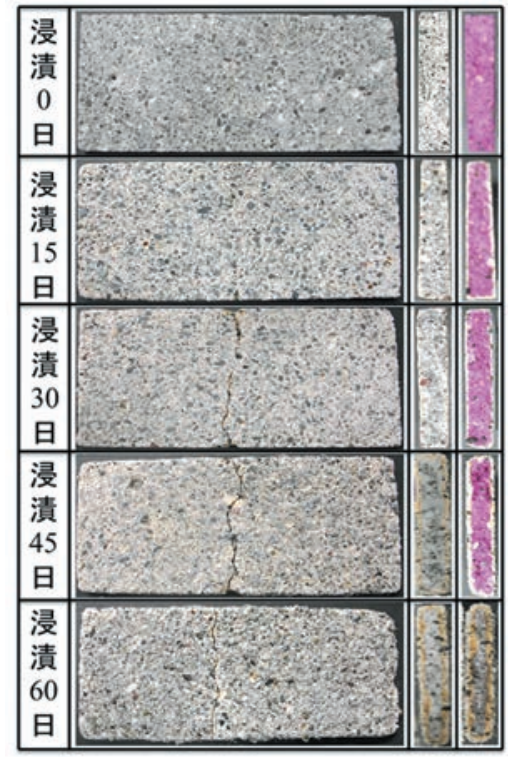

写真-1 薄片供試体の外観の推移
化を示す。また，水和物量と空隙率の関係も図に示す。 なお，総空隙量は水銀圧入法により算出された各細孔径 における空隙量の積分值である。

空隙率の経時変化（図－4）をみると，浸漬 30 日まで 減少し，それ以降は浸漬期間に伴って増加した。図－5 によれば, 総空隙量は浸漬 15 日まで減少し, それ以降は 浸漬期間に伴って増加した。この空隙率が増減した理由 は，水和物と硫酸イオンとの反応により二水セッコウが 析出することで空隙率が低下し，さらには，存在する空 隙以上に二水セッコウが析出されると微細な膨張ひび割 れが発生することで空隙率が増加するといった，緻密化 と膨張ひび割れ発生のプロセスを反映した結果であると 考えられる。細孔径分布の推移（図一6）をみると，浸漬 期間に伴って $0.1 \mu \mathrm{m}$ 付近の空隙量が減少するとともに, 最大空隙量時の細孔径が右にシフトしており, 浸漬前と 比較して粗大な空隙が増加しているようにみえる。しか しながら，セメント水和組織が脆弱化した試料では水銀 の圧入の際に空隙構造が変化することが予想される。硫 酸劣化した脆弱な試料の空隙構造の測定に関しては更な る検討を要するのが現状である。

図-7 に水和物量と空隙率の関係を示す。これによれ ば，空隙率と $\mathrm{CH}$ 量との間には明確な関連性がみられな い。しかしながら， $\mathrm{CH}$ 量/初期の $\mathrm{CH}$ 量 $=0.4$ 以上の部分 では, 空隙率が初期の空隙率より低下していることから, $\mathrm{CH}$ と硫酸イオンとの反応により析出した二水セッコウ による空隙の充填であると判断できる。また，空隙率と C-S-H 量との関係性に着目すると, C-S-H の増減に伴っ て空隙率が推移する傾向があるが，これは，C-S-H の減 少が空隙の増加の主要因というよりは, 浸漬 30 日の時点

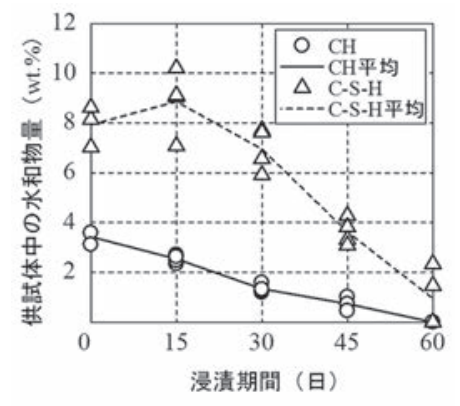

図-2 水和物量の推移

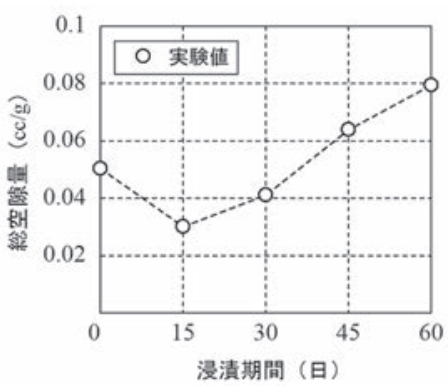

図－5 総空隙量の推移

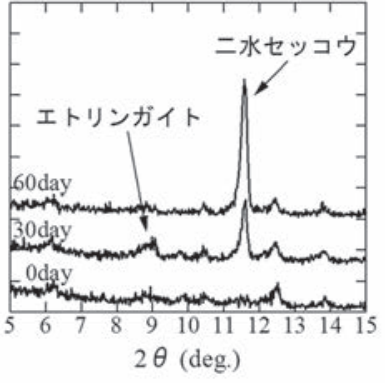

図-3 XRD の推移

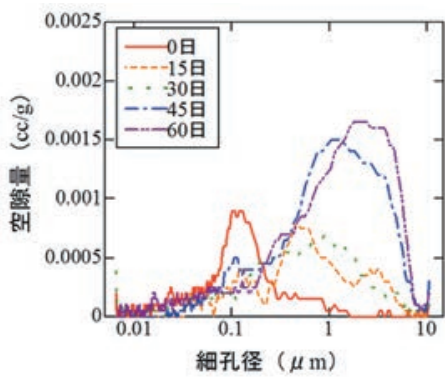

図-6 細孔径分布の推移

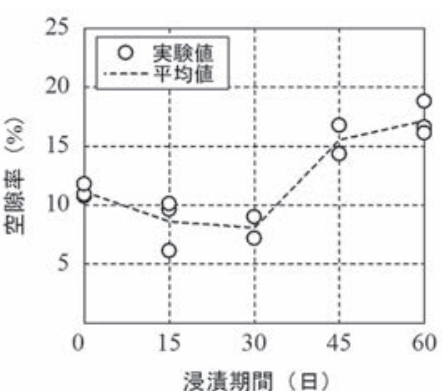

図-4 空隙率の推移

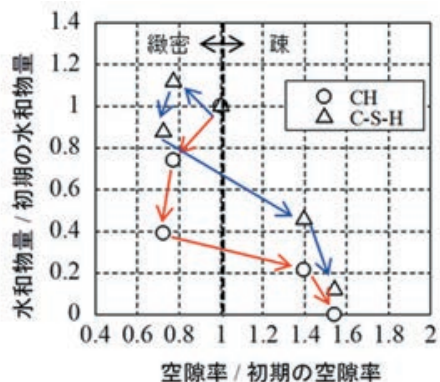

図-7 水和物量と空隙率の関係 
で微細な膨張ひび割れが発生したためと推察する。

\section{2 力学的性質の変化}

（1）曲げ応力変位曲線と引張軟化曲線の経時変化 硫酸溶液に浸漬させた薄片供試体による曲げ試験か ら得られた曲げ応力変位曲線の経時変化および荷重変位 曲線から逆解析的に算出した引張軟化曲線の経時变化を 図一8，9 に示す。なお，本実験では，荷重変位曲線の経 時変化を考察するにあたり, 薄片供試体中の寸法誤差に よる影響が無視できないため, 以下の式(2)から算出され た曲げ応力変位曲線によって経時的な変化を評価してい る。

$$
\sigma_{b}^{\prime}=\frac{3 \cdot P \cdot L}{2 \cdot b \cdot h^{2}}
$$

ここに, $\sigma_{b}^{\prime}$ : 見かけの曲げ応力, $P$ : 荷重, $L$ : スパン $\mathrm{mm}), b:$ 幅, $h:$ 厚さである。

曲げ応力変位曲線の経時変化（図－8）をみると, 浸 漬期間の増加に伴って，プレピークおよびポストピーク の勾配が緩やかであることが見受けられる。引張軟化曲 線の経時変化（図一9）をみると, 浸漬期間の増大に伴っ て, 引張強度の低下および最大ひび割れ幅の拡大が確認 できる。具体的には，浸漬前と浸漬 60 日の引張強度は $4.8 \mathrm{MPa}$ と $0.27 \mathrm{MPa}$, 最大ひび割れ幅は $0.064 \mathrm{~mm}$ と 0.165 $\mathrm{mm}$ であった。これは, 曲げ応力変位曲線のポストピー クの推移と一致する。また, 浸漬前と空隙率が低下した 浸漬 30 日を比較すると, 図ー10 に示すように異なるひ び割れ幅における引張応力負担が変化するということが 確認できる。すなわち，ひび割れ幅の狭い領域に着目す ると, 浸漬 30 日では負担できる引張応力が低くなってい ることがわかる。ひび割れ幅の広い領域に着目すると，
浸漬 30 日の方が, 最大ひび割れ幅が浸漬前と比して大き くなっているようにみえる。

（2）力学的性質の経時変化

各力学的性質 (弾性係数, 曲げ強度, 引張強度, 破壊 エネルギー，せん断強度）の実験結果を図－11，12，14， 15 に示す。また, 図一13 に引張強度と曲げ強度の関係を 示す。ここで，弾性係数は，以下の式(3)により，曲げ試 験から得られた荷重変位曲線の最大荷重の 3 分の 1 まで の割線弾性係数を算出した。

$$
E^{\prime}=\frac{P_{1 / 3} \cdot L^{3}}{4 \cdot \delta_{1 / 3} \cdot b \cdot h^{2}}
$$

ここに, $P$ : 荷重, $L:$ スパン $(50 \mathrm{~mm}), b:$ 幅, $h$ : 厚さ, $E^{\prime}$ : 見かけの弾性係数, $P_{1 / 3}$ : 最大荷重の 3 分の 1 の荷重, $\delta_{1 / 3}: P_{l / 3}$ の時の変位である。なお, 浸漬 60 日後では, せ ん断試験の治具の重さに薄片供試体が耐えられず，せん 断試験を行うことができなかったため，せん断強度は 0 とした。

図一11，12 をみると，弾性係数，曲げ強度，引張強度 は，いずれも浸漬期間の増加に伴って概ね一定の割合で 低下していることが確認できる。浸漬 60 日経過した時点 での弾性係数, 曲げ強度, 引張強度の平均值は，浸漬前 の平均值と比較して，それぞれ $4.6 \% ， 7.3 \% ， 4.0 \%$ 程度 であった。引張強度と曲げ強度の関係（図一13）をみる と，非常に高い関係性が確認できる。一方で，破壊エネ ルギーおよびせん断強度の経時変化（図－14,15）をみる と，それぞれ浸漬 30 日まで大きな変化はないが，それ以 降は低下寸る傾向にある。浸漬前と比較して浸漬 60 日の 破壊エネルギーの平均值は $17 \%$ 程度まで低下した。

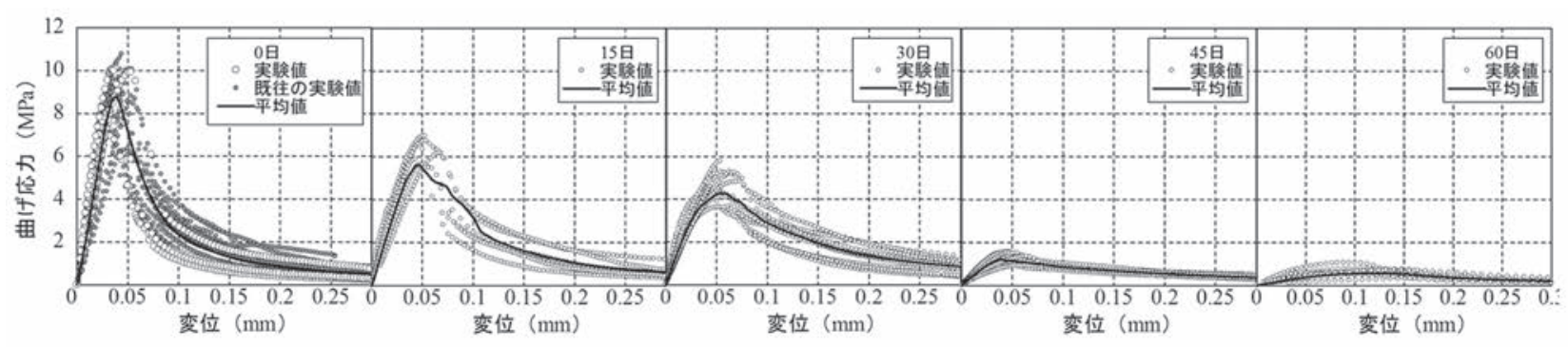

図-8 曲げ応力変位曲線の推移

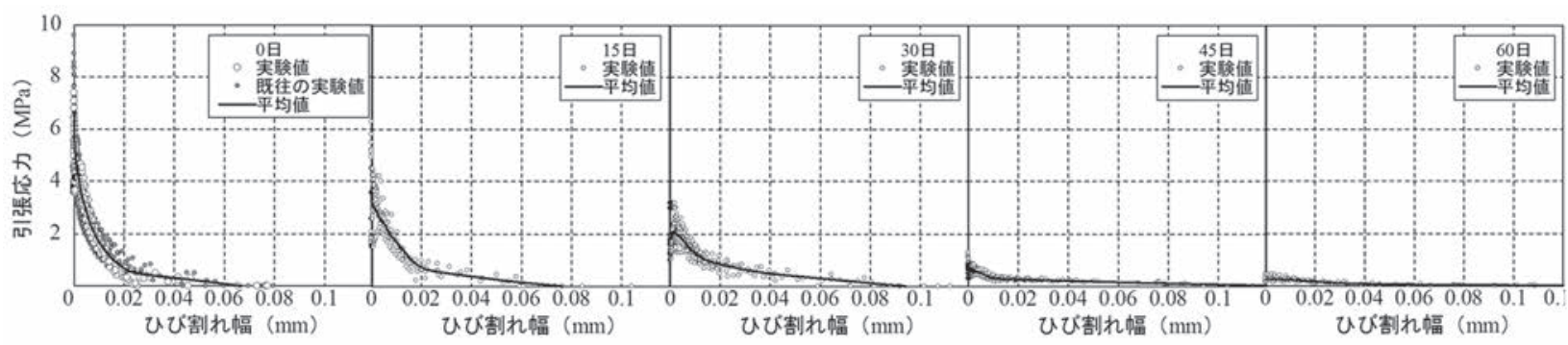

図-9 引張軟化曲線の推移 


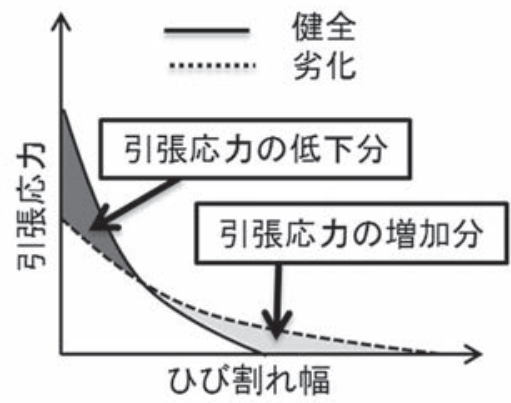

図ー10 異なるひび割れ幅における 引張応力負担

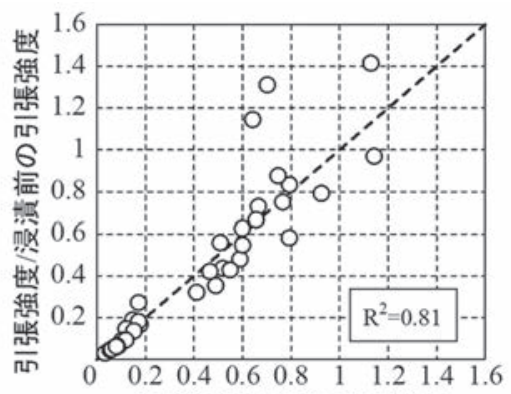

曲げ強度/浸漬前の曲げ強度

図-13＼cjkstart曲げ強度と引張強度の関係

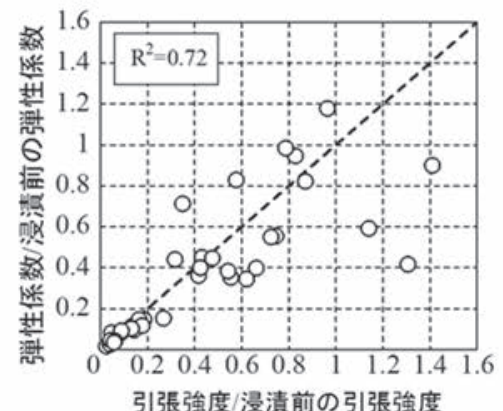

(a) 弾性係数一引張強度

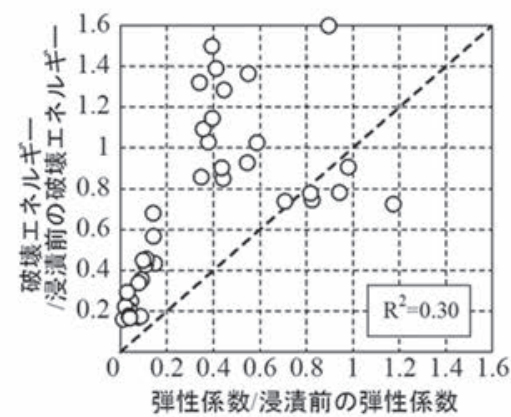

（d）破壊エネルギーー弾性係数

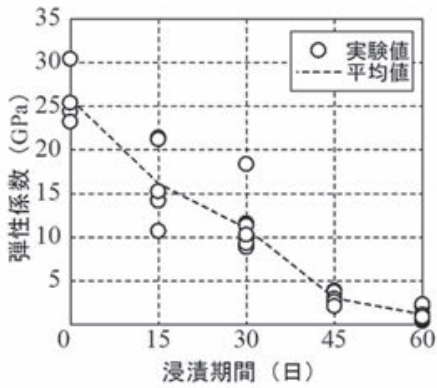

図-11 弾性係数の経時変化

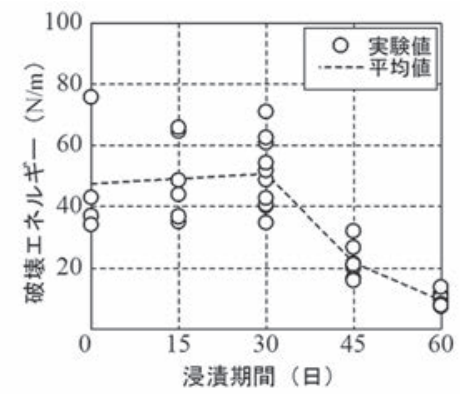

図-14 破壊エネルギーの経時変化

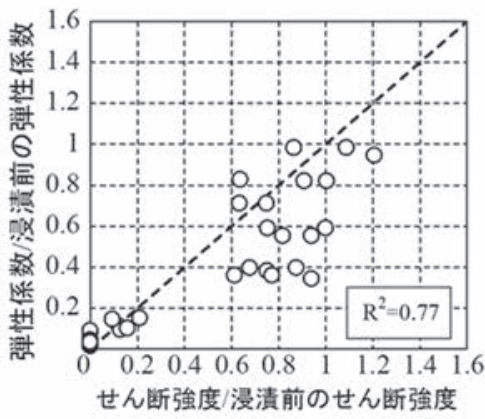

(b) 弾性係数一せん断強度

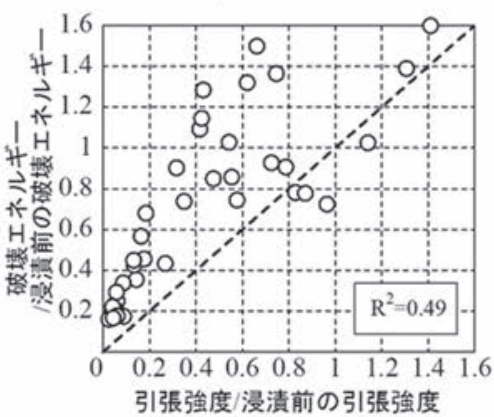

（e）破壊エネルギーー引張強度

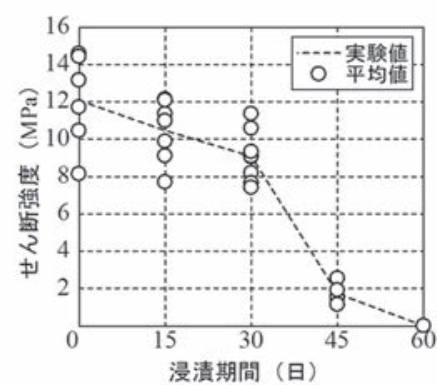

図-15 せん断強度の経時変化

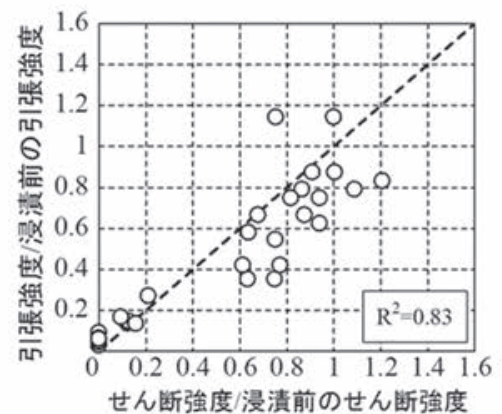

(c) 引張強度一せん断強度

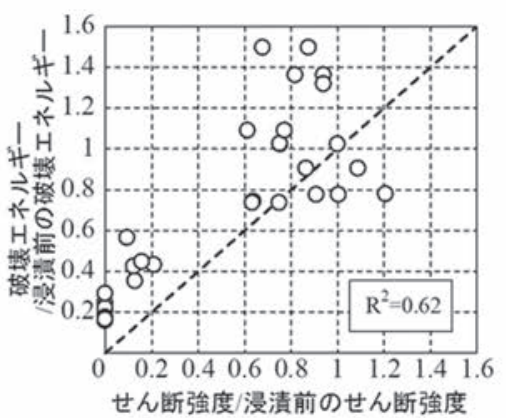

(f) 破壊エネルギーーせん断強度

\section{図-16 力学特性値の関係性}

浸漬 30 日までの破壊エネルギーの挙動は，引張軟化 曲線の推移から説明できる。破壊エネルギーは，浸漬期 間の増加とともにひび割れ幅の広い領域と狭い領域で負 担できる引張応力がそれぞれ増加, 減少するといった影 響を含むことから，図ー10において言及したように，浸 漬 30 日までのひび割れ幅の広い領域での引張応力の増 加分とひび割れ幅の狭い領域での引張応力の低下分が概
ね等しかったため，破壊エネルギーに変化がみられなか ったものと考えられる。さらに，著者らはこれまでに Ca 溶脱を対象とした $\mathrm{NaCl}$ 溶液を用いた浸漬実験 ${ }^{15)}$ を行っ ており, ひび割れ幅の広い領域における引張応力が増減 するといったことは表れなかった。ここで，Ca 溶脱では 硫酸劣化のように析出物が生成しないことを踏まえると, 本実験でみられたひび割れ幅の広い領域における引張応 
力の増分は，二水セッコウによる影響であると推察でき る。

\section{（3）力学的性質の関係性評価}

ここで, 力学特性值ごとの関係性を議論する。図ー16 に, 弾性係数と引張強度, 弾性係数とせん断強度, 引張 強度とせん断強度, 破壊エネルギーと弾性係数, 引張強 度，せん断強度の関係を示す。同図では，それぞれの力 学的性質を浸漬前の值で除して無次元化した值を用いて いる。

弾性係数, 引張強度, せん断強度のそれぞれの関係 (図 -16 (a)〜 (c) ) は, 高い決定係数を有していることがわ かる。また, 図ー16 (d)〜 (f) によれば, 破壊エネルギー とせん断強度との関係性はある程度高いが，破壊エネル ギーと弾性係数および引張強度との関係性は低いことが みてとれる。せん断破壊は, 微視的な領域において引張 破壊が連続して発生し，それらが結合することで生じる 破壊現象であると理解されていることから，ポストピー クの挙動を表す破壊エネルギーと関連性が比較的高かっ たものと考えられる。

\section{4. 物理化学的性質と力学的性質の関係}

本章では，これまでの実験結果に基づいて，物理化学 的性質と力学的性質との関係を示す。図一17 に, 各力学 的性質の平均值を浸漬前の值で除して正規化した值と, 薄片供試体中の $\mathrm{CH}$ 減少量, C-S-H 減少量, 空隙率の平 均值を浸漬前の值で除した值との関係を示す。
まず，各力学的性質と $\mathrm{CH}$ 減少量の関係を考察する。 弾性係数, 引張強度, せん断強度と $\mathrm{CH}$ 量の関係（図一 17 左列）をみると，非常に強い関係性を有しているとい える。一方で，破壊エネルギーと $\mathrm{CH}$ 量の関係（図－17 左列）に関しては, 薄片供試体中の $\mathrm{CH}$ 減少量と強い関 連性があるようにはみえない。また，各力学的性質と C-S-H 減少量との関係（図一17 中央列）をみると，弾性 係数は比較的強い関係性は確認できないが，一方で，引 張強度と破壊エネルギーとせん断強度に関しては, C-S-H 減少量との非常に関係性が強いことがわかる。次 に，各力学的性質と空隙率との関係（図一17 右列）を考 察すると，弾性係数，引張強度，せん断強度，破壊エネ ルギーの順に，空隙率との関連性が高くなる結果となっ た。3.1（2）において，空隙率は二水セッコウの析出に 伴う空隙の充填および微細なひび割れの発生の影響を反 映することを述べた。破壊エネルギーは空隙率と高い関 係性を有することから，二水セッコウの影響を受ける力 学パラメータであるとみなすことができるだろう。また, 二水セッコウが力学的性質に及ぼす影響は，二水セッコ ウの有する力学特性により, 以下の考察ができる。既往 の研究 ${ }^{16)}$ により，二水セッコウは，水分量などにより変 動するため一概には言えないが，本実験のモルタルにお ける弾性係数と曲げ強度の比が 3000 程度であることに 対し，二水セッコウでは曲げ強度は同程度であっても 700 程度と非常に低い值を有することから，ひび割れが 発生する変形量はモルタルより二水セッコウの方が大き いことが推察できる。すなわち，二水セッコウが力学的

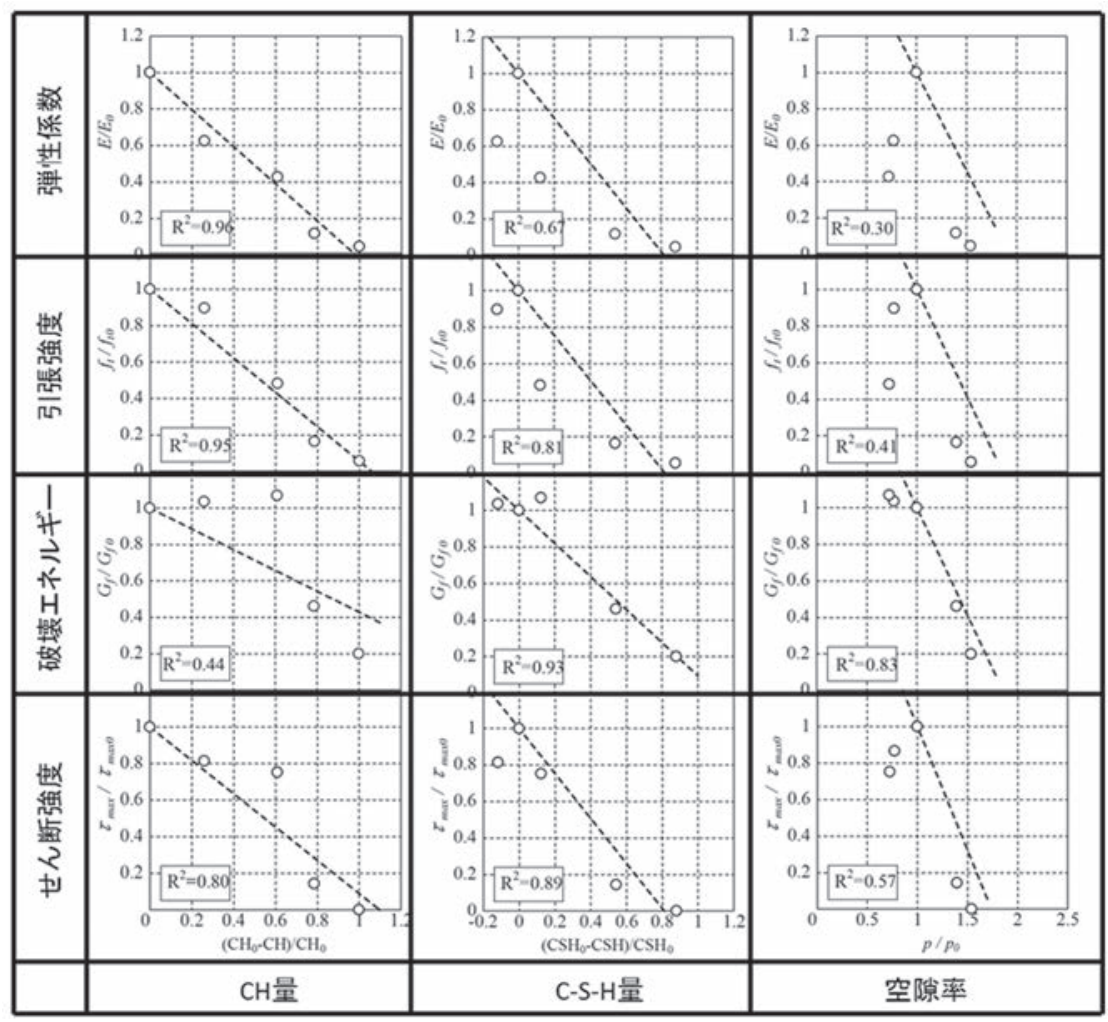

図-17 物理化学的性質と各力学特性値との関係 


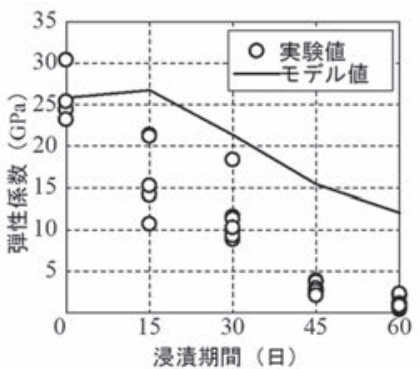

(a) 弾性係数

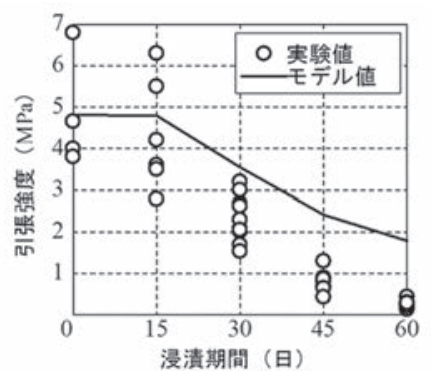

(b) 引張強度

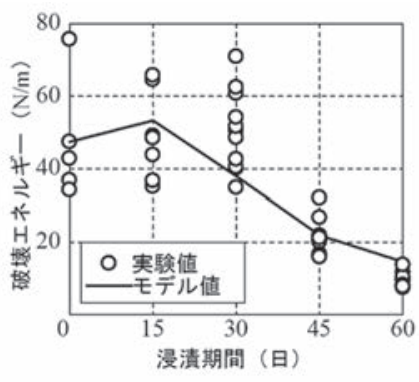

(c) 破壊エネルギー

\section{図-18 力学的性質の実験値とモデル值の対応}

性質におよぼす影響がひび割れ前の弾性域よりひび割れ 後の軟化域に顕在化することは, 二水セッコウの伸び能 力によって説明することができるだろう。

\section{5. 既往の提案モデルの適用性評価}

著者らは, $\mathrm{Ca}$ 溶脱により水和物量の減少に伴う空隙の 増加を変数とした弾性係数・引張強度・破壊エネルギー のモデル式 ${ }^{15}$ ) (以下, $\mathrm{Ca}$ 溶脱モデル) を提案した。そこ で, 前述の硫酸劣化により生成する二水セッコウの影響 を受けて変化した力学的性質を対象として Ca 溶脱モデ ルの適用を試み, 二水セッコウの影響がどの程度あるか を評価した。なお, 式中の各水和物減少項にかかる定数 は, 既往の $\mathrm{Ca}$ 溶脱を対象とした実験の結果から算定し た実験定数であり, CH および C-S-H が各力学的性質に 及ぼす影響度を表すと理解されたい。

$$
\begin{aligned}
& \frac{E}{E_{0}}=\exp \left[-\left\{0.4 \cdot \frac{\Delta C H}{C H_{0}}+1.0 \cdot \frac{\Delta C S H}{C S H_{0}}\right\}\right] \\
& \frac{f_{t}}{f_{t 0}}=\exp \left[-\left\{1.0 \cdot \frac{\Delta C H}{C H_{0}}+0.7 \cdot \frac{\Delta C S H}{C S H_{0}}\right\}\right] \\
& \frac{G_{f}}{G_{f 0}}=\exp \left[-\left\{0.1 \cdot \frac{\Delta C H}{C H_{0}}+0.4 \cdot \frac{\Delta C S H}{C S H_{0}}\right\}\right]
\end{aligned}
$$

ここで, $E, E_{0}$ : 弾性係数および浸漬前の弾性係数, $f_{t}$, $f_{t 0}$ : 引張強度および浸漬前の引張強度, $G_{f}, \mathrm{G}_{f 0}$ : 破壊工 ネルギーおよび浸漬前の破壊エネルギー, $\triangle C H$ : 薄片供 試体中の $\mathrm{CH}$ の減少量, $\mathrm{CH}_{0}$ : 浸漬前の薄片供試体中の $\mathrm{CH}$ 量, $\triangle \mathrm{CSH}$ : 薄片供試体中の $\mathrm{C}-\mathrm{S}-\mathrm{H}$ 量, $\mathrm{CSH}_{0}$ : 浸漬 前の供試体中の C-S-H 量である。

図一18に弾性係数, 引張強度, 破壊エネルギーの実験 值とモデル值の対応を示す。これをみると, 弾性係数, 破壊エネルギー（図一18 (a)，(c)）は，浸漬 15 日までの
C-S-H の若干の増加の影響を受けてモデル值は浸漬前よ り高くなり，引張強度（図一18（b)）に関しては，概ね 一定值を示した。浸漬 15 日以降では，いずれの力学的性 質においても低下した。弾性係数と引張強度（図一18 (a)，(b)）は浸漬 15 日以降のモデル值の低下勾配は実験 值のそれより低く，破壊エネルギー（図一18（c））に関 しては值としてはモデル值は実験值を捉えてはいるもの の, 浸漬 30 日まで変化がなくそれ以降に低下寸るといっ た挙動は捉えることができなかった。

今後, 析出物の生成に伴う析出物固有の特性や緻密 化・微細な膨張ひび割れが力学的性質に影響を包括的に 捉えることが可能なモデルの構築を試みる予定である。

\section{6. まとめ}

本研究により得られた知見を以下に示す。

1 ）本実験結果から, 硫酸溶液に浸漬させた薄片供試 体中の物理化学的性質の変化を捉えた。すなわち, 薄片供試体中の水和物量は経時的に直線的に減 少したが, 総空隙量および空隙率は浸漬 30 日ま で低下しその後増加したことから，二水セッコウ の析出による空隙の充填および膨張ひび割れ発 生のプロセスを反映する結果となった。

2 ）硫酸劣化による物理化学的性質の変化に伴って, 曲げ応力変位関係のプレピークおよびポストピ ークの勾配は緩慢になった。逆解析により算出さ れた引張軟化曲線においても, ひび割れ後の軟化 勾配が緩やかになることが確認された。さらに詳 細にみると, 浸漬前と空隙率が低下した浸漬 30 日を比較すると, 引張軟化曲線の経時変化から, ひび割れ幅の狭い領域では引張応力の負担が低 下し，ひび割れ幅の広い領域では引張応力の負担 が増加した。

3 ）弾性係数, 曲げ強度, 引張強度, 世ん断強度は, 硫酸劣化による物理化学的性質の経時的な変化 に伴って低下した。一方で, 破壊エネルギーは, 浸漬 30 日まで祭立った変化が見られなかったが, それ以降は浸漬期間に伴って急激に低下した。 
4 ）物理化学的性質と力学的性質の関係から, 弾性係 数, 引張強度, せん断強度は $\mathrm{CH}$ 減少量と非常に 強い関係性が確認できた。C-S-H 減少量に関して は, 引張強度, 破壊エネルギー, せん断強度と高 い関係性が確認できた。また, 空隙率に関しては, 弾性係数, 引張強度, せん断強度, 破壊エネルギ 一の順に，空隙率との関係性が高い結果となった。

5 ）空隙率は二水セッコウの析出の影響を反映してい ると考えられることから, 空隙率との関係性が高 い破壊エネルギーは二水セッコウの析出による 影響が顕在化する力学的性質である可能性を示 唆した。

6 ）著者らが過去に提案した $\mathrm{Ca}$ 溶脱モデルの適用を 試みたところ，空隙に関する情報のみでは弾性係 数, 引張強度, 破壊エネルギーの実験值を再現す ることは困難であり，二水セッコウの影響をモデ ル中に組み込む必要があることを確認した。

謝辞: 本論文は, 日本学術振興会特別研究員 DC2 の助成 を受けて行われた。ここに記し，謝意を表する。

\section{参 考 文 献}

1）水上国男：コンクリート構造物の耐久性シリーズ, 化学的腐食, 技 報堂出版, 1986 .

2）土木学会編: コンクリートの化学的侵食・溶脱に関する研究の現状, コンクリート技術シリーズ， No.53，2003.

3）中本至: 下水道施設におけるコンクリート構造物の化学的劣化, 土 木学会論文集, No.472/V-20, pp.1-pp.11, 1993.8.

4）蔵重勲: 硫酸によるコンクリート劣化のメカニズムと予測手法, 東 京大学学位論文, 2002 .

5）大脇英司ほか: 硫酸イオンの浸入と機械的特性の変化からみたセメ ント硬化体の変質, Journal of Ceramic Society of Japan, 109, pp.1039-1045, 2001.

6) 久田真, 松谷竜一: 酸性雨成分の作用によるセメント硬化体の物性 変化，土木学会論文集，No.746/V-61，pp.197-pp.204，2003.11.

7) E. F. Irassar: Sulfate resistance of blended cement: prediction and relation with flexural strength, Cement and Concrete Research, Vol.20, pp.209-pp.218, 1990.

8）上田洋ほか:酸性雨の作用を受けたコンクリートの特性および劣化 予測，土木学会論文集 E，Vol.63，No.1，pp.27-pp.41，2007.1.

9) M. Zhang, M. Jiang, J. Chen: Variation of flexural strength of cement mortar attacked by sulfate ions, Engneering Fracture Mechanics, Vol.75, pp.4948-pp.4957, 2008.

10) A. Gabrisova, J. Havlica: Stability of calcium sulphoaluminate hydrates in water solutions with various $\mathrm{pH}$ values, Cement and Concrete Research, Vol.21, pp.1023-pp.1027, 1991.

11）魚本健人, 峰松敏和: コンクリートのせん断強度試験方法に関する 基礎的研究, コンクリート工学, Vol.19, No.4, pp.106-117, 1981.4.

12）三浦泰人, 佐藤靖彦: 隻微視的スケールに基づく直接二面せん断試 験法に関寸る実験的検討, 土木学会, 第 67 回年次学術講演会, V-253, pp.505-506, 2012.9.

13） 日本コンクリート工学協会:切欠きはりを用いたコンクリートの破 壊エネルギー試験方法, 2003.

14）小林一輔：コア採取によるコンクリート構造物の劣化診断法, 森北 出版, 1998.

15) T. Miura, Y. Sato: Modeling of tensile behavior of mortar immersed in solutions including chloride ions, The 2nd International Conference on Microstructure Related Durability of Cementitious Composites, No.30, CD-ROM, 2012.4

16）清水聰, 若松盈, 服部哲幸, 竹内信行, 中村真一：セッコウ硬化体 の曲げ強度, ワイブル係数および吸水性におよぼす混水量の影響, 石膏と石灰, No.213, pp.61-68, 1988

(原稿受理年月日 : 2014 年 7 月 17 日)

\section{Relationships Between Transformation of Cement Hydrates and Meso-scale Mechanical Characteristics of Mortar Deteriorated by Sulfate Attack By Taito Miura, Yasuhiko Sato and Hikaru Nakamura}

Concrete Research and Technology, Vol.26, 2015

Synopsis: In this study, meso-scale thin mortar specimens were immersed in a sulfuric acid solution for 60 days and then subjected to three-point bending tests and shear tests to clarify the mechanical behaviors of mortar in containing cement hydrates transubstantiated under sulfate attack. In particular, tensile behaviors, namely elastic modulus, tensile strength and fracture energy, and shear strength, were determined from the load-displacement curves using back analysis and shear tests, respectively. Following the mechanical tests, chemical analyses were also carried out to clarify how the amount of hydrates, which were quantities of $\mathrm{CH}$ and $\mathrm{C}-\mathrm{S}-\mathrm{H}$, the existence of precipitates, porosity and pore volume distribution affect mechanical characteristics. As a result, it was found that the relationships between physico-chemical properties and elastic modulus and tensile strength differ from the relationships between physico-chemical properties and fracture energy and shear strength. Furthermore, the applicability of the proposed model based on the relationships between porosity and strength was verified through comparison of the calculated and experimental results.

Keywords: Sulfuric Acid, Cement Hydrates, Porosity, Pore Distribution, Tensile Behavior, Shear Strength 